\title{
Manajemen Kepala Sekolah dalam Meningkatkan Fungsi Guru di Sekolah Menengah Atas Negeri 4 Merangin
}

\author{
Basri $^{1}$, Khairinal ${ }^{2}$ dan Firman ${ }^{3}$ \\ ${ }^{1}$ Mahasiswa Magister Manajemen Pendidikan Universitas Jambi, Indonesia \\ ${ }^{2}$ Dosen Universitas Jambi, Indonesia \\ 3Dosen Universitas Jambi, Indonesia \\ Correspondence email: ribas2580@gmail.com
}

\begin{abstract}
Abstrak. Tujuan penelitian ini adalah untuk mengetahui manajemen kepala sekolah dalam meningkatkan fungsi guru di SMA Negeri 4 Merangin. Penelitian ini adalah penelitian kualitatif dengan meneliti kondisi obyek yang alamiah, dimana peneliti adalah sebagai instrumen kunci, pengambilan sampel sumber data dilakukan secara purposive sampling, teknik pengumpulan dengan trainggulasi, analisis data bersifat indukatif/kualitatif, dan hasil penelitian lebih menekankan makna. Hasil penelitian ini adalah manajemen kepala sekolah dalam meningkatkan fungsi guru di SMA Negeri 4 Merangin dilakukan memberikan kesempatan guru melakukan pengembangan diri seperti melanjutkan pendidikan ke Magister (S2), mengikuti pelatihan kurikulum 2013, menargetkan sertifikasi guru dan adaptasi guru terhadap Pendidikan. Kepala sekolah melakukan pengorganisasian dalam meningkatkan fungsi guru di SMA Negeri 4 Merangin yaitu pembagian tugas ditawarkan kepada setiap personil sesuai dengan kemampuannya. Pada aspek penggerakan kepala sekolah dalam bentuk dorongan, komunikasi dan koordinasi kepada setiap personil untuk bekerja, meskipun kurang sesuai visi dan fasilitas yang terbatas. Kepala sekolah melakukan pengawasan tidak dievaluasi secara berkala. Kendala kepala sekolah dalam meningkatkan fungsi guru di SMA Negeri 4 Merangin adalah status guru belum semua PNS sehingga mempengaruhi kesejahteraan dan profesionalitas. Kemudian kualitas dan kuantitas media/alat praktikum masih terbatas serta anggaran yang belum mendukung operasional sekolah dan peluang mengikuti pelatihan yang sedikit.
\end{abstract}

Kata Kunci: Manajemen Kepala Sekolah, Fungsi Guru

\begin{abstract}
The purpose of this study was to determine the principal's management in improving the function of teachers at SMA Negeri 4 Merangin. This research is a qualitative research by examining the condition of natural objects, where the researcher is the key instrument, the sampling of data sources is carried out by purposive sampling, the collection technique is by training, the data analysis is inductive/qualitative, and the results of the study emphasize the meaning. The result of this study is that the principal's management in improving the function of teachers at SMA Negeri 4 Merangin is carried out by providing opportunities for teachers to carry out self-development such as continuing their education to Masters (S2), participating in 2013 curriculum training, targeting teacher certification and teacher adaptation to education. The principal organizes in improving the function of teachers at SMA Negeri 4 Merangin, namely the division of tasks offered to each personnel according to their abilities. In the aspect of moving the principal in the form of encouragement, communication and coordination to every personnel to work, even though it is not in accordance with the vision and limited facilities. The principal of the school supervises is not evaluated on a regular basis. The principal obstacle in improving the function of teachers at SMA Negeri 4 Merangin is that the status of teachers is not all civil servants so that it affects welfare and professionalism. Then the quality and quantity of media/practice tools are still limited and the budget does not support school operations and the opportunity to participate in training is few.
\end{abstract}

Keywords: Principal Management, Teacher Function

\section{PENDAHULUAN}

Kepala sekolah sebagai seorang manajer dituntut untuk memiliki skill yang handal agar roda organisasi berjalan sehat, bijaksana dan cerdas dalam menciptakan keputusan-keputusan yang dapat dijadikan dasar atau acuan bagi warga sekolah. Kemampuan kepala sekolah dalam menciptakan kebijakan-kebijakan bermutu sangat menentukan efektifitas program dan mutu pendidikan sekolah, karena secara langsung kebijakan yang ditetapkan akan mempengaruhi mekanisme manajemen kerja organisasi sekolah dalam mencapai tujuan yang diharapkan. Tugas kepala sekolah dalam mengelola sekolah harus memiliki data-data dan catatan-catatan yang berkaitan dengan komponen-komponen penyelenggaraan pendidikan. Untuk menjamin terlaksananya tugas pendidikan secara baik hendaklah terlebih dahulu dipersiapkan manajemen mutu, elastis, dinamis, dan kondusif yang memungkinkan bagi pencapaian tujuan tersebut. Hal ini berarti bahwa pihak manajerial sekolah dituntut agar dapat menjalankan manajemen mutu dengan cara yang paling baik sesuai dengan keadaan dan situasi lingkungan.

Pada organisasi pendidikan, manajemen juga diterapkan pada tenaga kependidikan, dimaksudkan untuk meningkatkan pelayanan organisasi pendidikan itu. Manajemen adalah suatu bentuk kerja, yang mana dalam 
Basri, Khairinal dan Firman, Manajemen Kepala Sekolah dalam Meningkatkan Fungsi Guru di Sekolah Menengah Atas Negeri 4 Merangin

melaksanakan kerja tersebut harus melaksanakan kegiatan-kegiatan tertentu yang dikenal sebagai administrasi yang meliputi perencanaan, perorganisasian, pengarahan dan pengendalian sumber daya organisasi, motivasi serta pengontrolan. Sekolah sebagai sebuah organisasi tidak terlepas dari leadership dan manajemen yang baik. Adapun manajemen kepala sekolah adalah usaha kepala sekolah dalam untuk melaksanakan fungsi manajemen terhadap sumber daya sekolah dalam mencapai tujuan pendidikan (Karwati dan Priansa, 2013: 119-121). Indikator manajemen kepala sekolah adalah usaha kepala sekolah melakukan perencanaan, pengorganisasian, kepemimpinan dan pengawasan terhadap kegiatan sekolah.

Berdasarkan indikator ini dapat dijelaskan bahwa kepala sekolah harus memiliki kemampuan untuk merencanakan program kerja (planning); mewujudkan dan menjalankan kinerja suatu organisasi dalam struktur organisasi atau intansi yang dipimpinnya (organization); bergerak memberikan contoh kepada bawahan sebelum menggerakkan, mengerjakan, melaksanakan program kerja kantor yang dipimpinnya secara bersama (actuating) dan setelah semua berjalan dan terlaksana dengan baik sesuai yang diprogramkan maka sebagai seorang pemimpin haruslah mengontrol kinerja bawahannya apakah berjalan sesaat, atau berjalan biasa-biasa saja, atau tidak berjalan (controling) dan sudah menjadi tugas seorang pemimpin untuk mengadakan kontrol/pengawasan sekiranya terdapat masalah di lapangan maka pemimpin juga berkewajiban mencari solusi/jalan keluarnya.

Kepala sekolah bertanggung jawab dalam mengatur, mengelola, melaksanakan, dan mengendalikan kegiatankegiatan pendidikan yang diekmbangkan di sekolah. Maju mundurnya suatu sekolah berada ditangan kepala sekolah, karena peran kepala sekolah sangat strategis dan menentukan bagi pengembangan sekolah terutama dalam menggerakkan dan memperdayakan komponen-komponen sekolah seperti guru dan Kepala sekolah harus mengetahui secara utuh pengelolaan sekolah serta harus mempunyai target kemajuan sekolah tersebut. Manajemen sekolah menggariskan konsep partipasi pada tingkat paling bawah, yaitu sekolah dengan segala komunitasnya. Komunitas sekolah, dimaksud adalah kepala sekolah, guru, staf tata usaha, pengurus komite sekolah, orang tua siswa, masyarakat yang peduli, dan siswa. Dengan manajemen partisipatif bermakna bahwa kepala sekolah membutuhkan sistem kerja yang teratur untuk mensinergikan keragaman orang-orang dengan tugas pokok dan fungsi yang beragam pula agar bermuara pada satu koridor pendidikan dan pembelajaran pada level kompleks sekolah (Danim, 2013: 74).

Selaku manajer, kepala sekolah mempunyai tanggung jawab yang sangat besar terhadap kelancaran aktivitas pendidikan di sekolah yang dipimpinnya. Dengan asumsi bahwa peran pokok kepala sekolah terdapat dalam kesanggupannya untuk mempengaruhi lingkungan melalui kepemimpinannya yang dinamis. Kepala sekolah merupakan orang kunci dalam pemeliharaan dan pengembangan pengajaran di sekolah. Ia selaku pemimpin instruksional harus mampu menggerakkan sekolahnya mencapai kemajuan dan dapat mengidentifikasi bakat-bakat dan kemampuan-kemampuan sumber daya manusia di lembaga pendidikan yang dipimpinnya. Maka kepala sekolah menjadi seorang koordinator pengetahuan dan kemampuan-kemampuan personilnya, dan ia akan berusaha bagi pengembangan dan kemajuan seluruh program intruksional.

Guru adalah tenaga profesional yang bertanggung jawab untuk mendidik dan mengajarkan anak didik dengan pengalaman yang dimilikinya, baik dalam wadah formal maupun wadah non formal, dan melalui upaya ini maka anak didik bisa menjadi orang yang cerdas dan beretika tinggi. Tugas guru memang sangat besar di samping mengajar juga mendidik. Menjadi guru bukanlah pekerjaan yang mudah, seperti yang dibayangkan sebagian orang, hanya bermodal penguasaan materi dan menyampaikannya kepada siswa sudah cukup. Hal ini belumlah dapat dikategorikan sebagai guru yang memiliki pekerjaan profesional, mereka harus memiliki berbagai keterampilan, kemampuan khusus, mencintai pekerjaannya, menjaga kode etik guru, dan masih banyak hal lain yang perlu dikuasai oleh guru.

Guru merupakan faktor yang sangat dominan dan paling penting dalam sistem pendidikan karena sering dijadikan tokoh teladan, bahkan menjadi tokoh identifikasi diri. Oleh sebab itu, guru seyogyanya memiliki kemampuan yang memadai untuk mengembangkan siswanya secara utuh, guru perlu menguasai berbagai hal sebagai kemampuan yang dimilikinya. Guru memiliki arti dan peranan yang sangat penting dalam pendidikan. Hal ini disebabkan ia memiliki tanggung jawab dan menentukan arah pendidikan. Guru dalam proses belajar-mengajar harus memiliki kemampuan tersendiri guna mencapai harapan yang dicita-citakan dalam melaksanakan pendidikan pada umumnya dan proses pembelajaran pada khususnya. Salah satu tugas yang harus dilaksanakan oleh guru di satuan pendidikan ialah memberikan pelayanan kepada para siswa atau anak didik yang selaras dengan tujuan satuan pendidikan. Dalam keseluruhan proses pendidikan guru merupakan faktor utama yang bertugas mendidik, guru memegang berbagai jenis peranan mau tidak mau harus dilaksanakan secara profesional oleh guru.

Adapun ciri-ciri guru yang profesional menurut Mulyasa (2008: 22) adalah: 1) Mengerti dan dapat menerapkan teori belajar sesuai taraf perkembangan peserta didik, 2) Mengerti dan dapat menerapkan metode pembelajaran yang bervariasi, 3) Mampu mengembangkan dan menggunakan berbagai alat, media dan sumber belajar yang relevan dan 4) Mampu mengorganisasikan dan melaksanakan program pembelajaran. Menurut Mukhtar dan Iskandar (2013: 141), 
Basri, Khairinal dan Firman, Manajemen Kepala Sekolah dalam Meningkatkan Fungsi Guru di Sekolah Menengah Atas Negeri 4 Merangin

orientasi profesional guru adalah kecakapan individu guru yang menjadi sentral tugasnya dan bukan organisasinya, sehingga mereka mempunyai kecenderunan untuk melihat permintaan organisasi sebagai penekanan atau gangguan, dan mereka akan mencari jalan untuk menghindarinya. Tetapi, saat ini hal itu tidak mungkin terjadi, sejak para profesional harus memiliki sebuah organisasi tepat mereka bekerja.

Profesi guru bisa dilihat dari usaha keras, keahlian, dan berat ringannya pekerjaan yang dimiliki wajar mendapat kompensasi yang adil berupa gaji dan tunjangan dan fasilitas yang memadai. Tugas guru sebagai pembimbing, pelatih, dan pengajar merupakan pekerjaa berat, guru harus memeras otak, mental, dan fisik untuk mencerdaskan kehidupan bangsa. Demikian juga guru harus diberi kesempatan untuk mengembangkan diri dan jabatannya atau dilakukan profesionalisasi terhadap guru. Seperti mengikuti kursus, pelatihan, penataran, melanjutkan pendidikan yang lebih tinggi. Kemudian diberi kesempatan menduduki jabatan sesuai keahlian yang dimilikinya (profesional) (Permadi dan Arifin, 2013: 11).

Guru adalah tenaga profesional yang bertanggung jawab dengan sungguh-sungguh untuk mendidik dan mengajarkan anak didik dengan pengalaman yang dimilikinya, baik dalam wadah formal maupun wadah non formal. Dengan upaya ini maka anak didik bisa menjadi orang yang anak didik menjadi orang yang cerdas dan beretika tinggi. Guru sebagai komponen yang bertanggung jawab dalam proses dan misi pendidikan secara umum serta proses pembelajaran secara khusus, sangat rentan dengan berbagai persoalan yang mungkin muncul apabila rencana awal proses pembelajaran ini tidak direncanakan secara matang dan bijak, hal ini akan berimplikasi pada gagalnya proses pembelajaran. Sejak awal guru harus mampu berperan sebagai pelaku pengelolaan kelas, sekaligus sebagai evaluator dalam proses. Efektifitas dan mutu dalam proses pembelajaran haruslah mencapai tujuan pendidikan sebagaimana yang ditetapkan. Hal ini sudah barang tentu akan menimbulkan masalah dalam proses pendidikan secara umum maupun dalam proses pembelajaran secara khusus.

Wahjosumidjo (2007: 83), menjelaskan bahwa kepala sekolah sebagai figur sentral harus menyadari bahwa terbentuknya kebiasaan, sikap, dan perilaku dalam konteks kultur sekolah sangat dipengaruhi oleh manajemen dan kepemimpinan sekolah, dan cara dia melihat perkembangan ke depan yang bersifat visioner. Perkembangan disiplin guru dan pegawai sekolah yang lebih baik dan sehat harus dimulai dari manajemen kepala sekolah yang dikelola kepala sekolah dan guru di sekolah. Masih menurut Wahjosumidjo (2007: 84), kepala sekolah yang mampu membangun tim kerja, kerja dari guru dan pegawai, terbuka untuk jalur komunikasi dengan lingkungan, luas akses informasi akan mampu mengembangkan kultur positif sekolah demi terwujudnya sekolah mandiri yang berada di atas kemampunya sendiri.

Persoalan fungsi guru di SMA Negeri 4 Merangin dalam konteks manajemen kepala sekolah berdasarkan studi awal melalui wawancara yang dilakukan pada 20 Desember 2020 adalah menemukan bahwa guru belum memahami secara maksimal teori belajar sesuai taraf perkembangan peserta didik, kedua, guru kurang memami metode pembelajaran yang bervariasi sesuai kurikulum 2013 dan belajar daring. Ketiga, guru masih sulit mengembangkan dan menggunakan berbagai alat, media dan sumber belajar yang relevan dan keempat, guru kesulitan mengorganisasikan dan melaksanakan program pembelajaran.

Adapun tujuan dari penelitian ini adalah 1) Untuk mengetahui kepala sekolah menyusun perencanaan dalam meningkatkan fungsi guru di SMA Negeri 4 Merangin; 2) Untuk mengetahui kepala sekolah melakukan pengorganisasian dalam meningkatkan fungsi guru di SMA Negeri 4 Merangin; 3) Untuk mengetahui kepala sekolah melakukan pengawasan dalam meningkatkan fungsi guru di SMA Negeri 4 Merangin; dan 4) Untuk mengetahui kendala kepala sekolah dalam meningkatkan fungsi guru di SMA Negeri 4 Merangin.

\section{LANDASAN TEORI}

\section{Konsep Manajemen Kepala Sekolah}

Manajemen sebagai suatu kemampuan yang selanjutnya menjadi cikal bakal suatu profesi (Engkoswara dan Komariah, 2012: 85). Ada lagi pendapat lain mengatakan bahwa poses manajemen mempunyai beberapa tahapan yaitu: Penentuan Tujuan, perumusan strategi, perencanaan, penentuan program kerja, perorganisasian, penggerakan sumber daya manusia, pemantauan kegiatan operasional, pengawasan, penilaian serta penciptaan dan penggunaan sistem umpan balik (Siagian, 2011: 33). Manajemen adalah penerapan fungsi-fungsi: perencanaan, pengorganisasian, pengarahan, pelaporan, pengkoordinasian, pembiayaan, dan pengawasan dengan menggunakan dan memanfaatkan fasilitas maupun sumberdaya yang tersedia (Sagala, 2010: 56).

Usaha peningkatan mutu pendidikan di sekolah perlu didukung oleh kemampuan manajerial kepala sekolah. Sekolah perlu berkembang maju dari tahun ke tahun. Kenyataan menunjukkan bahwa tingkat kemajuan sekolah sangat ditentukan oleh sejauhmana tingkat kemajuan manajemen dan administrasi sekolah. Manajemen selalu berkaitan dengan kehidupan organisasi sosial di mana terdapat sekelompok orang yang menduduki berbagai jenjang tingkat 
Basri, Khairinal dan Firman, Manajemen Kepala Sekolah dalam Meningkatkan Fungsi Guru di Sekolah Menengah Atas Negeri 4 Merangin

kepemimpinan dan sekelompok orang lain yang tanggung jawab utamanya adalah menyelenggarakan kegiatan operasional. Pandangan ini sangat mendasar karena keberhasilan seseorang yang menduduki jabatan manajerial tidak lagi diukur dari keterampilannya menyelenggarakan kegiatan operasional, melainkan dari kemahiran dan kemampuannya menggerakkan orang lain dalam organisasi.

Manajemen sekolah membutuhkan kemampuan profesional kepala sekolah sebagai pemimpin pendidikan. Kepala sekolah bertanggung jawab dalam mengatur, mengelola, melaksanakan, dan mengendalikan kegiatan-kegiatan pendidikan yang diekmbangkan di sekolah. Maju mundurnya suatu sekolah berada ditangan kepala sekolah, karena peran kepala sekolah sangat strategis dan menentukan bagi pengembangan sekolah terutama dalam menggerakkan dan memperdayakan komponen-komponen sekolah dan Kepala sekolah harus mengetahui secara utuh pengelolaan sekolah serta harus mempunyai target kemajuan sekolah tersebut. Kepala sekolah sebagai seorang manajer pada suatu sekolah hendaknya dapat mengelola keadaan yang akan berjalan sesuai dengan program masing-masing individu, terutama guru yang akan menjadi senjata andalan dalam suatu organisasi pendidikan. Setiap sekolah sudah pasti berharap agar mutu pendidikan di lembaganya meningkat supaya sekolahnya dipartisipasi oleh banyak siswa. Selaku pemimpin, kepala sekolah mempunyai tanggung jawab yang sangat besar terhadap kelancaran aktifitas pendidikan di sekolah yang dipimpinnya. Dengan asumsi bahwa peran pokok kepala sekolah terdapat dalam kesanggupannya untuk mempengaruhi lingkungan melalui kepemimpinannya yang dinamis. Kepala sekolah merupakan orang kunci dalam pemeliharaan dan pengembangan pengajaran di sekolah. Ia selaku pemimpin intruksional harus mampu menggerakkan sekolahnya mencapai kemajuan dan dapat mengidentifikasi bakat-bakat dan kemampuan-kemampuan sumber daya manusia di lembaga pendidikan yang dipimpinnya. Maka kepala sekolah menjadi seorang koordinator pengetahuan dan kemampuan-kemampuan personilnya, dan ia akan berusaha bagi pengembangan dan kemajuan seluruh program instruksional.

Manajer sekolah harus menyusun tugas dengan mendahulukan tujuan utama organisasi. Dalam upaya pencapaian tujuan, harus mendelegasikan tugas-tugasnya kepada staf (Pramono, 2013:18). Sungguh masih teramat banyak kelemahan, kekurangan dan kesalahan-kesalahan yang terdapat dalam menata dan menjalankan tata aturan Allah SWT di dunia ini dalam mempersiapkan masa depan (Zainuddin, 2007: 22). Untuk itu, seorang pemimpin harus mengambil tanggung jawab menyelesaikan masa itu. Tanggung jawab adalah unsur yang nyata dalam organisasi wujudnya dalam kesadaran personel berupa petunjuk-petunjuk tentang apa yang hendak di perbuat sebagai pekerjaanya. jika atasan memberi tugas yang samar-samar, bawahan akan menerima gambaran yang samar-samar pula tentang pekerjaannya, dan dengan itu rasa tanggung jawab yang tak lengkap, yang niscaya akan menimbulkan infisiensi dalam organisasi (Wahab, 2008: 237).

Dengan berfungsinya peran kepala sekolah, maka diyakini bahwa sekolah yang dipimpinnya akan mengalami perkembangan dan peningkatan mutu pendidikan, serta pemenuhan partisipasi masyarakat sekolah. Peran aktif kepala sekolah belum bisa dilaksanakan maksimal, karena adanya beberapa faktor penghambat dalam upaya tersebut yang mungkin terkendalanya pelaksanaan teknis dalam proses perbaikan mutu pendidikan. Menurut Mc. Farland yang dikutip oleh Sagala (2009: 145) mengemukan bahwa kepemimpinan merupakan suatu proses dimana pimpinan digambarkan akan member perintah atau pengarahan, bimbingan atau mempengaruhi pekerjaan orang lain dalam memilih dan mencapai tujuan yang telah ditetapkan.

Manajemen sekolah meliputi usaha merencanakan program kerja (planning); mewujudkan dan menjalankan kinerja suatu organisasi dalam struktur organisasi atau instansi yang dipimpinnya (organization); bergerak memberikan contoh kepada bawahan sebelum menggerakkan, mengerjakan, melaksanakan program kerja kantor yang dipimpinnya secara bersama (actuating) dan setelah semua berjalan dan terlaksana dengan baik sesuai yang diprogramkan maka sebagai seorang pemimpin haruslah mengontrol kinerja bawahannya apakan berjalan sesaat, atau berjalan biasa-biasa saja, atau tidak berjalan (controlling) dan sudah menjadi tugas seorang pemimpin untuk mengadakan kontrol/pengawasan sekiranya terdapat masalah di lapangan maka pemimpin juga berkewajiban mencari solusi/jalan keluarnya, dengan demikian kepemimpinan organisasi akan berjalan dengan baik sesuai dengan apa yang diharapkan bersama (Kompri, 2014: 2-4).

\section{Konsep Manajemen Kepala Sekolah dalam Meningkatkan Fungsi Guru}

Peran guru tidak bisa lepas dari karakteristik pekerja profesional. Sebagai suatu pekerjaan profesional, sudah barang tentu kemampuan guru harus secara terus-menerus ditingkatkan. Peningkatan mutu guru dengan mendasarkan pada kemauan dan usaha para guru sendiri. Artinya, guru tidak harus didikte dan diberi berbagai arahan dan instruksi. Yang penting adalah perlu disusun standar profesional guru 'yang akan dijadikan acuan pengembangan mutu guru dan pembinaan guru diarahkan pada sosok guru pada era globalisasi atau milenial ini. Sosok guru ini penting karena guru merupakan salah satu bentuk soft profession bukannya hard profession seperti dokter atau insinyur. Sudah barang 
Basri, Khairinal dan Firman, Manajemen Kepala Sekolah dalam Meningkatkan Fungsi Guru di Sekolah Menengah Atas Negeri 4 Merangin

tentu pendidikan dan pembinaan guru akan berbeda dengan dokter atau insinyur. Karena hakekat kerja dua bentuk profesi tersebut berbeda (Sugiyono, 2014: 132).

Guru dalam perspektif dalam manajemen kepala sekolah meliputi usaha perencanaan, pengorganisasian, penggerakan dan pengawasan untuk mencapai tujuan disiplin yang telah ditetapkan dengan menggunakan potensi yang ada secara efektif dan efisien. Hal tersebut dapat dijelaskan sebagai berikut:

a. Perencanaan

Perencanaan adalah inti manajemen karena semua kegiatan organisasi yang bersangkutan didasarkan pada rencana. Dengan perencanaan itu, maka para pengambil keputusan bisa menggunakan sumber daya yang ada secara berdaya guna dan berhasil guna (secara efektif dan efisien). Demikian pula perencanaan sumber daya manusia (human resources planning) adalah merupakan inti dari manajemen sumber daya manusia, karena dengan adanya perencanaan maka kegiatan seleksi, pelatihan dan pengembangan, serta kegiatan-kegiatan lain yang berkaitan dengan sumber daya manusia lebih terarah. Perencanaan pendidikan menurut Engkoswara \& Komariah (2012) adalah proses menetapkan keputusan yang berkaitan dengan tujuan-tujuan yang akan dicapai, sumber-sumber yang akan diberdayakan, dan teknik-teknik yang dipilih secara tepat untuk melaksanakan tindakan selama kurun waktu tertentu agar penyelenggaraan sistem pendidikan dapat dilaksanakan secara efektif, efisien dan bermutu.

Perencanaan guru dan pegawai dilakukan dengan memperhitungkan aspek masa lampau. Dengan berpijak pada pengalaman masa lampau, perencanaan akan dapat memperkirakan jenis aktivitas apa yang dapat mensejahteraan guru dan pegawai. Keadaan guru dan pegawai yang senyatanya sekarang ini harus diketahui oleh perencanaan guru dan pegawai. Semua keterangan, informasi dan data mengenai guru dan pegawai harus dikumpulkan, agar dapat ditetapkan kegiatannya, dan konsekuensinya dari kegiatan tersebut mengangkut biayanya, tenaganya, dan sarana prasarananya.

b. Pengorganisasian

Menurut Engkoswara \& Komariah (2012) pengorganisasian adalah proses menyusun organisasi formal dengan melakukan aktivitas merancang struktur, menganalisis pekerjaan, menganalisis kualifikasi pekerjaan, mengelompokkan dengan membagi pekerjaan, mengkoordinasikan pekerjaan serta memantu pelaksanaan pekerjaan. Kepala sekolah sebagai pemimpin harus bisa menempatkan posisi guru dan staf sesuai dengan bidangnya (keahliannya) karena jika tidak pasti akan menemui kendala besar yang mengakibatkan kehancuran dalam organisasi, termasuk dalam mengelola partisipasi masyarakat yang ada. Kepala sekolah menjalankan fungsi manajer terhadap pelaksanaan pekerjaan di sekolah. Melalui fungsi ini kepala sekolah dapat berupaya untuk meningkatkan sumber daya sekolah yang ada. Kegiatan kepala sekolah dalam keseluruhan proses pendidikan merupakan kegiatan yang integral terhadap keseluruhan proses kegiatan pendidikan lainnya. Selaku pemimpin kepala sekolah mempunyai tanggung jawab yang sangat besar terhadap kelancaran aktivitas pendidikan di sekolah yang dipimpinnya. Dengan asumsi bahwa tugas pokok kepala sekolah adalah mempengaruhi lingkungan melalui kepemimpinannya yang dinamis dan pengembangan pembelajaran di sekolah. ini mengingatkan kita tentang pentingnya berorganisasi dan sebaliknya bahayanya suatu kebenaran yang tidak diorganisir melalui langkah-langkah yang kongkrit dan strategi-strategi yang mantap. Maka tidak ada garansi bagi perkumpulan apa pun yang menggunakan identitas Islam meski memenangkan pertandingan, persaingan maupun perlawanan jika tidak dilakukan pengorganisasian yang kuat.

c. Penggerakan

Menurut Siagian (1989: 169), penggerakan dapat didefinisikan sebagai "keseluruhan usaha, cara, teknik dan metode untuk mendorong para anggota organisasi agar mau dan ikhlas bekerja dengan sebaik mungkin demi tercapainya tujuan organisasi dengan efesien, efektif dan ekonomis." Dapat dijelaskan dari pengertian ini bahwa cara terbaik untuk menggerakan para anggota organisasi adalah dengan cara pemberian komando dan tanggung jawab utama para bawahan terletak pada pelaksanaan perintah yang diberikan itu.

Penggerakan merupakan usaha yang dilakukan oleh seorang pimpinan kepada para bawahannya dengan jalan mengarahkan dan memberikan petunjuk agar mereka mau melaksanakan tugasnya dengan baik menuju tercapainya tujuan yang telah ditentukan bersama. Kepala sekolah sebagai figur sentral harus menyadari bahwa terbentuknya kebiasaan, sikap, dan prilaku dalam konteks kultur sekolah sangat dipengaruhi oleh pribadi, gaya kepemimpinan, dan cara dia melihat perkembangan ke depan yang bersifat visioner. Perkembangan kultur sekolah yang lebih baik dan sehat harus dimulai dari kepemimpinan kepala sekolah. Kepala sekolah yang mampu membangun tim kerja, kerja dari guru, staf tata usaha dan guru dan pegawai, terbuka untuk jalur komunikasi dengan lingkungan, luas akses informasi akan mampu mengembangkan kultur positif sekolah demi terwujudnya sekolah mandiri yang berada di atas kemampunya sendiri.

Kepala sekolah selaku pemimpin harus mampu menggerakkan sekolahnya mencapai kemajuan dengan mengidentifikasi bakat-bakat dan kemampuan-kemampuan sumber daya manusia di lembaga pendidikan yang 
Basri, Khairinal dan Firman, Manajemen Kepala Sekolah dalam Meningkatkan Fungsi Guru di Sekolah Menengah Atas Negeri 4 Merangin

dipimpinnya. Maka kepala sekolah menjadi seorang koordinator pengetahuan dan kemampuan-kemampuan personilnya, dan ia akan berusaha tenaga profesional bagi pengembangan program sekolah. Kepemimpinan yang baik menciptakan iklim yang kondusif tercapainya tujuan bersama dengan manajemen yang prima. Kepemimpinan merupakan kemampuan yang harus dimiliki oleh setiap pemimpin dalam memimpin suatu kelompok, baik terorganisasi maupun tidak.

Pemimpin menjadi barometer keberhasilan kelompok dalam proses perencanaan, pelaksanaan, pemberian motivasi, pengawasan sehingga tercapainya tujuan-tujuan bersama dalam kelompok tersebut. Dengan demikian, kepemimpinan yang baik dapat meningkatkan kemampuan bawahan untuk menunjukan kualitas kerja secara maksimal, sehingga pencapaian tujuan dapat dilakukan secara efesien dan efektif. Pemimpin, dalam kepemimpinannya menampilkan beragam model dan gaya yang akhirnya akan mengklasifikasikan pemimpin tersebut ke dalam tipe-tipe kepemimpinan tertentu.

Orang-orang yang duduk pada posisi pimpinan yang benar-benar piawai dalam menjalankan tugas pokok dan fungsinya untuk mencapai tujuan organisasi secara efektif, efisien, dan dengan akuntabilitas tertentu. Mereka harus memiliki etos kerja tinggi, bermartabat, dan mampu memberdayakan seluruh sumber daya yang tersedia (Danim, 2008: 20).

Orang-orang diberdayakan ketika mereka mampu menjalankan kekuasaannya secara lebih bebas, seperti menggunakan keahlian mereka. Praktik kepemimpinan dan manajemen yang menimbulkan pemberdayaan antara lain pengunaan manajemen partisipatif, membebaskan orang dari aturan yang terlalu mengekang, melatih orang dengan keahlian yang mereka butuhkan, dan mengunakan struktur tim. Sebelum memberdayakan orang lain, cara karyawan yang level tanggung jawabnya di atas rata rata. Kemampuan dan motivasi adalah faktor sukses untuk pemberdayaan (DuBrin, 2009: 229).

\section{d. Pengawasan}

Menurut Engkoswara \& Komariah (2012: 219) pengawasan adalah proses untuk mengetahui ada tidaknya penyimpangan dalam pelaksanaan rencana agar secara dilakukan upaya perbaikan sehingga dapat dimastikan bahwa aktivitas yang dilaksanakan secara riil merupakan aktivitas yang sesuai dengan apa yang direncanakan. Manajer mempunyai tugas membantu para pegawai dalam mengembanngkan potensi yang mereka miliki dalam melaksanakan tugasnya sehari-hari sesuai dengan harapan. Pengambilan keputusan partisipatif, yaitu pelibatan warga kepala sekolah secara langsung dalam pengambilan keputusan, maka rasa memiliki warga kepala sekolah dapat meningkat. Peningkatan rasa memiliki ini akan menyebabkan peningkatan rasa tanggung jawabkan meningkatkan dedikasi warga terhadap kepala sekolahnya. Inilah esensi pengambilan keputusan partisipatif. Baik peningkatan mutu kepala sekolah maupun pengambilan keputusan partisipatif tersebut kesemuanya ditujukan untuk meningkatkan mutu sekolah berdasarkan kebijakan pendidikan nasional yang berlaku.

Berdasarkan teori di atas dapat disintesiskan bahwa manajemen kepala sekolah adalah usaha kepala sekolah dalam untuk melaksanakan fungsi manajemen terhadap sumber daya sekolah dalam mencapai tujuan pendidikan. Indikator manajemen kepala sekolah adalah usaha kepala sekolah sebagai manajer melakukan perencanaan, pengorganisasian, kepemimpinan dan pengawasan semua program-program sekolah.

\section{Konsep Guru}

Guru adalah tenaga kependidikan yang berpartisipasi dalam penyelenggaraan pendidikan dengan tugas khusus sebagai profesi guru (Yahya, 2013: 20). Undang-Undang Republik Indonesia Nomor 14 Tahun 2005 tentang Guru dan Dosen menjelaskan bahwa guru adalah pendidik profesional dengan tugas utama mendidik, mengajar, membimbing, mengarahkan, melatih, menilai, dan mengevaluasi peserta didik pada pendidikan anak usia dini jalur pendidikan formal, pendidikan dasar, dan pendidikan menengah. Dengan demikian adalah guru adalah tenaga profesional yang berprofesi mendidik, mengajar, membimbing, mengarahkan, melatih, menilai, dan mengevaluasi peserta didik pada pendidikan anak usia dini jalur pendidikan formal, pendidikan dasar, dan pendidikan menengah.

Profesi pendidik berhubungan dengan kegiatan mendidik, membimbing dan mengajarkan sejumlah ilmu pengetahuan kepada peserta didik. tugas guru adalah merencanakan dan melaksanakan proses pembelajaran, menilai hasil pembelajaran, melakukan bimbingan dan pelatihan, melakukan penelitian dan pengkajian dan membukan komunikasi dengan masyarakat (Sagala, 2009: 6). Guru yang bekerja harus memiliki sikap yang profesional atau memiliki profesionalitas. Hawwa (2011: 398-399) dalam bukunya yang berjudul Al-Islam menjelaskan bahwa di antara hak kerja adalah menyelesaikan suatu pekerjaan hingga paripurna, tidak melakukan kecurangan dalam bekerja, ia harus kuat dengan pekerjaannya, mengetahui seluk beluk dan mekanisme kerjanya, dapat dipercaya dengan pekerjaan dan menepati janji pada waktunya.

Berdasarkan ayat ini, menurut analisis Nata (2012: 220-224), terdapat beberapa catatan penting dalam hubungannya dengan tugas guru, yaitu: 
Basri, Khairinal dan Firman, Manajemen Kepala Sekolah dalam Meningkatkan Fungsi Guru di Sekolah Menengah Atas Negeri 4 Merangin

a. Seorang tenaga yang profesional adalah seorang yang al-amin (terpercaya), al-hafidz (dapat menjaga amanah) dan al-wafiya (dapat mewarat sesuatu dengan baik.

b. Seorang tenaga pendidikan profesional dalam pandangan Islam adalah seorang pendidikan yang memiliki keahlian.

c. Seorang tenaga pendidikan profesional dalam pandangan Islam adalah seorang yang bertindak adil, yakni memberi hak kepada yang memilikinya dengan cara yang paling efektif atau tidak berbelit-belit (iyshal alhaqq ila shabibihi min aqrab al-thuruq ilaihi).

Guru adalah tenaga profesional yang bertanggung jawab untuk mendidik dan mengajarkan anak didik dengan pengalaman yang dimilikinya, baik dalam wadah formal maupun wadah non formal, dan melalui upaya ini maka anak didik bisa menjadi orang yang cerdas dan beretika tinggi. Tugas guru memang sangat besar di samping mengajar juga mendidik. Menjadi guru bukanlah pekerjaan yang mudah, seperti yang dibayangkan sebagian orang, hanya bermodal penguasaan materi dan menyampaikannya kepada siswa sudah cukup. Hal ini belumlah dapat dikategorikan sebagai guru yang memiliki pekerjaan profesional, mereka harus memiliki berbagai keterampilan, kemampuan khusus, mencintai pekerjaannya, menjaga kode etik guru, dan masih banyak hal lain yang perlu dikuasai oleh guru.

\section{Fungsi Guru}

Fungsi guru diwujudkan dengan guru bertanggung jawab untuk mendidik dan mengajarkan anak didik dengan pengalaman yang dimilikinya, baik dalam wadah formal maupun wadah non formal, dan melalui upaya ini maka anak didik bisa menjadi orang yang cerdas dan beretika tinggi. Tugas guru memang sangat besar di samping mengajar juga mendidik. Menjadi guru bukanlah pekerjaan yang mudah, seperti yang dibayangkan sebagian orang, hanya bermodal penguasaan materi dan menyampaikannya kepada siswa sudah cukup.

Peranan serta posisi yang besar ini dimiliki oleh semua guru dalam pembelajaran. Jabatan sebagai guru di lembaga pendidikan merupakan pekerjaan profesional, yang dalam pelaksanaannya memerlukan suatu keahlian khusus. Dalam pengertian tersebut, guru bukan hanya sekedar orang yang berdiri di depan kelas untuk menyampaikan materi pengetahuan (mata pelajaran), akan tetapi sebagai fasilitator dalam mentransformasikan ilmu pengetahuan serta kreatif dalam mengarahkan perkembangan anak didiknya untuk menjadi individu yang dibutuhkan dalam masyarakat. Agar dapat melaksanakan tugasnya dengan baik dan profesional, maka guru harus memiliki sejumlah kemampuan.

Peningkatan fungsi guru yang dilakukan secara makro dan mikro ini tidak akan terlepas dari kata kunci tersebut.

a. Knowledge (Pengetahuan). Dalam pengembangan profesional guru, menambah ilmu pengetahuan adalah hal yang mutlak. Kita harus mempelajari segalam macam pengetahuan, akan tetapi kita juga harus mengadakan skala prioritas, akan tetapi kita juga harus mengadakan skala prioritas. Kenapa demikian? Karena dalam menunjang keprofesionalan sebagai guru, menambah ilmu pengetahuan tentang keguruan sangat perlu. Namu bukan berarti kita hanya memperlajari satu disiplin ilmu saja. Semakin banyak ilmu pengetahuan yang kita pelajari, semakian banyak pula wawasan kita tentang berbagai ilmu.

b. Ability (Kemampuan). Kemampuan paling dasar yang diperlukan adalah kemampuan dalam mengantisipasi setia perubahan yang terjadi. Oleh karena itu, seorang yang profesional tentunya tidak ingin ketinggalan dalam percaturan global ini. Dengan dmeikian, ia harus mengantisipasi perubahan itu dnegan banyak membaca supaya bertambah ilmu pengetahuannya.

c. Skill (Keterampilan). Bagi seorang guru yang tugasnya mengajar dan peranannya di dalam kelas

d. Attitude (sikap diri). Sikap diri seorang terbentuk oleh suasana lingkungan yang mengitarinya. Seorang anak pastu mulai belajar tentang dirinya melalui lingkungan yang terdekat, yaitu orang tua. Oleh karena itu, masa kecil adalah masa peniruan (karena setiap gerak-gerik yang dilihatnya) akan dia tiru. Oleh karena itu, sikap diri ini perlu dikembangkan (tentunua yang baik). Salah satu contoh bila kita di rumah sangat ramah terhadap keluarga, besar kemungkinan di sekolah pun kita akan bersikap ramah terhadap anak didik dan teman sejawat. Dengan demikian, kita bisa melihat bahwa sikap diri merupakan kepribadian seseorang.

e. Habit (kebiasaan Diri). Kebiasaan adalah suatu kegiatan yang terus menerus dilakukan yang tumbuh dari dalam pikiran. Pengembangan kebiasan diri harus dilandasi dengan kesadaran bahwa usaha tersebut membutuhkan proses yang cukup panjang. Kebiasaan positif di antaranya adalah menyapa dengan ramah, memberikan pujian kepada anak didik dengan tulus, menyampaikan rasa simpati, menyampaikan rasa penghargaan kepada kerabat, teman sejawat, atau anak didik yang berprestasi, dan lain-lain (Nurdin, 2004: 115-116).

Menurut Permadi dan Arifin (2013: 13), fungsi guru akan ditunjukkan oleh lima sikap utama atau indikator yaitu:

a. Keinginan untuk selalu menampilkan perilaku hasil kerja yang mendekati sesuai dengan standar ideal.

b. Senantiasa berusaha meningkatkan dan memilihara citra profesi. 
Basri, Khairinal dan Firman, Manajemen Kepala Sekolah dalam Meningkatkan Fungsi Guru di Sekolah Menengah Atas Negeri 4 Merangin

c. Memiliki keinginan yang kuat untuk senantiasa mengejar kesempatan pengembangan profesional yang dapat meningkatkan dan memperbaiki kualitas pengetahuan dan keterampilannya.

d. Senantiasa mengejar dan mengutamakan kualitas/mutu dan cita-cita dalam profesi.

e. Memiliki kebanggaan terhadap profesinya.

Menurut pendapat Muhaimin (2003: 216), ada standar tertentu yang dimiliki oleh seorang guru yang profesional, dengan ciri-ciri sebagai berikut:

a. Adanya komitmen mereka sendiri untuk menjunjung tinggi martabat kemanusiaan lebih dari pada kepentingan dirinya sendiri.

b. Mereka harus menjalani suatu persiapan profesional dalam jangka waktu tertentu guna mempelajari dan memperoleh pengetahuan khusus tentang konsep dan prinsip dari profesi itu sehingga statusnya ditingkatkan.

c. Selalu harus menambah pengetahuan jabatan agar terus bertumbuh dalam jabatan.

d. Memiliki kode etik jabatan.

e. Memiliki daya maupun keaktifan intelektual untuk mampu menjawab masalah-masalah yang dihadapi dalam setiap perubahan.

f. Selalu ingin belajar lebih dalam mengenai suatu bidang keahlian.

g. Jabatannya dipandang sebagai suatu karir hidup.

h. Menjadi anggota dari suatu organisasi, misalnya kelompok kepala sekolah, atau guru bidang studi tertentu.

Profesionalitas mengacu kepada sikap para anggota profesi terhadap profesinya serta derajat pengetahuan dan keahlian yang mereka miliki dalam rangka melakukan pekerjaannya. Parameter kemajuan belajar anak dapat diukur dengan fungsi gurunya. Profesionalisasi dimaksudkan untuk mempertahankan guru berkualitas dan membantu guru baru melakukan transisi menjadi guru efektif yang berkualitas tinggi, memerlukan tekad seluruh anggota lembaga pendidikan yang berdedikasi meningkatkan proses pendidikan dan pembelajaran (Stronge dan Catano (2008: 43). Tujuan peningkatan fungsi guru adalah tercapainya guru yang baik. Menurut Peter G. Beider (Rosyada, 2003: 115117), kriteria guru yang baik, di antaranya adalah sebagai berikut:

a. Seorang guru yang baik harus benar-benar berkeinginan untuk menjadi guru yang baik. Guru yang baik harus mencoba dan terus mencoba, dan biarkan siswa-siswa tahu bahwa dia sedang mencoba, dan bahkan dia juga sangat menghargai siswanya yang senantiasa melakukan percobaan-percobaan, walaupun mereka tidak pernah sukses dalam apa yang mereka kerjakan. Dengan demikian, para siswa akan menghargai guru, walaupun guru tidak sebaik yang diinginkan, namun guru akan terus membantu siswa yang ingin sukses.

b. Seorang guru yang baik berani mengambil risiko, mereka berani menyusun tujuan yang sangat muluk, lalu mereka berjuang untuk mencapainya. Jika apa yang mereka inginkan itu tidak terjangkau, mereka biasanya suka dengan uji coba berisiko tersebut.

c. Seorang guru yang baik memiliki sikap positif. Tidak baik bagi seorang guru untuk mempermasalahkan profesi keguruannya dengan mengaitkan pada indeks gaji yang tidak memadai. Kalau tidak suka dengan indeks gaji seperti itu, ambil putusan segera, dan cari alternatif yang lebih baik. Tidak boleh profesi keguruan menjadi terhina oleh guru sendiri hanya karena indeks gajinya tidak memadai.

d. Guru yang baik berpikir bahwa mengajar adalah sebuah tugas menjadi orang tua siswa, yakni bahwa guru punya tanggung jawab terhadap siswa sama dengan tanggung jawab orang tua terhadap-putra-putrinya sendiri dalam batas-batas kompetensi keguruan, yakni guru punya otoritas untuk mengarahkan siswa sesuai basis kemampuannya.

e. Guru yang baik selalu mencoba memotivasi siswa-siswinya untuk hidup mandiri, lebih independent khususnya untuk sekolah-sekolah menengah atau college, mereka harus sudah mulai dimotivasi untuk mandiri dan independent.

Peningkatan fungsi guru perlu dilakukan, karena guru yang profesionalah yang akan mendukung peningkatan mutu pendidikan. Untuk itu, pembinaan mutu guru profesional tidak dapat diabaikan, atau ditunda-tunda lagi. Berbagai sekolah unggul yang ada di Indonesia, selalu memiliki guru yang unggul pula. Guru yang profesional dalam pandangan Islam. Selain harus memiliki kompetensi pedagogik, kepribadian, sosial dan akademik, juga harus didasarkan pada visi dan spirit ajaran Islam, sehingga memiliki makna ibadah kepada Allah SWT., dan terhinda dari pengaruh materialisme dan hedonisme yang menjadi sebab jatuhnya mutu pendidikan. Dalam rangka meningkatkan mutu guru profesional, perlu dipertimbangkan untuk menghidupkan kembali sekolah-sekolah keguruan, kolaborasi antara fakultas non keguruan dan non keguruan, melibatkan kaum profesional sebagai tenaga pengajar pada pendidikan profesi keguruan, dan dengan menerapkan sistem magang, konsep guru berantai dan berjenjang, serta tutor sebaya yang dimonitor, disupervisi dan dibina oleh guru senior berpengalaman dan profesional dalam mendidik caloncalon guru (Nata, 2012: 231). 
Pembinaan tenaga guru yang profesional perlu dilakukan, karena guru yang profesionalah yang akan mendukung peningkatan mutu pendidikan. Untuk itu, pembinaan mutu guru profesional tidak dapat diabaikan, atau ditunda-tunda lagi. Berbagai sekolah unggulan yang ada di Indonesia, selalu memiliki guru yang unggul pula. Guru yang profesional dalam pandangan Islam. Selain harus memiliki kompetensi pedagogik, kepribadian, sosial dan akademik, juga harus didasarkan pada visi dan spirit ajaran Islam, sehingga memiliki makna ibadah kepada Allah SWT, dan terhinda dari pengaruh materialisme dan hedonisme yang menjadi sebab jatuhnya mutu pendidikan. Dalam rangka meningkatkan mutu guru profesional, perlu dipertimbangkan untuk menghidupkan kembali sekolah-sekolah keguruan, kolaborasi antara fakultas non keguruan dan non keguruan, melibatkan kaum profesional sebagai tenaga pengajar pada pendidikan profesi keguruan, dan dengan menerapkan sistem magang, konsep guru berantai dan berjenjang, serta tutor sebaya yang dimonitor, disupervisi dan dibina oleh guru senior berpengalaman dan profesional dalam mendidik calon-calon guru (Nata, 2012: 231).

Parameter kemajuan belajar anak dapat diukur dengan kinerja gurunya. Fungsi guru sesungguhnya lebih banyak ditentukan oleh kualitas ilmu yang diberikan dalam pelayanan pendidikan pada sebuah satuan pendidikan, dengan kata lain terangkum pada kemampuan/ kecakapan yang dimilikinya. Hal ini sangat beralasan karena guru adalah orang yang paling sering bersentuhan langsung dengan peserta didik dalam proses pembelajaran. Dalam menangani gejalagejala ketertinggalan dalam bidang pendidikan diperlukan guru dan memiliki profesionalitas.

\section{METODE PENELITIAN}

Penelitian ini merupakan sebuah studi kualitatif deskriptif yang mengungkapkan, menemukan dan menggali informasi tentang manajemen sekolah dalam meningkatkan fungsi guru di SMA Negeri 4 Merangin. Penelitian kualitatif yang penulis pilih bersumber dari pengamatan kualitatif (Kirk dan Miler, 1986: 9), yaitu sistem keyakinan dasar pada peneliti postpositivisme adalah eksperimental/manipulatif yang dimodifikasi, maksudnya menekankan sifat ganda yang kritis. Memperbaiki ketidakseimbangan dengan melakukan penelitian dalam latar yang alamiah, yang lebih banyak menggunakan metode-metode kualitatif, lebih tergantung pada teori-grounded (grounded-theory) dan memperlihatkan upaya (reintroducing) penemuan dalam proses penelitian”.

Pemunculan karakter penelitian kualitatif di atas menjadi pedoman penelitian, yang nantinya mengarahkan terbentuknya pola penelitian yang global. Pendekatan kualitatif digunakan untuk menguraikan, menggambarkan, menggali dan mendeskripsikan manajemen sekolah tersebut, pendekatan kualitatif yang dimaksud adalah bahwa terlebih dahulu peneliti mencari literatur atau teori yang berkaitan dengan penelitian, kemudian teori tersebut dibandingkan dengan kondisi lapangan penelitian. Penelitian deskriptif dilakukan dengan tujuan untukmendiskripsikan atau menggambarakan fakta-fakta mengenai populasi secara sistematis, dan akurat. Dalam penelitian deskriptif fakta-fakta hasil penelitian disajikan apa adanya (Cresswell, 2013). Hasil penelitian deskriptif sering digunakan, atau dilanjutkan dengan dilakukannya penelitian analitik. Deskriptif yang dimaksud pada penelitian ini adalah penelitian studi kasus yaitu rancangan penelitian yang mencakup pengkajian satu unit penelitian secara intensif, misalnya satu pasien, keluarga, kelompok, komunitas, atau institusi. Karakteristik studi kasus adalah subjek yang diteliti sedikit tetapi aspek-aspek yang diteliti banyak.

Dalam penelitian ini, peserta penelitian direncanakan di SMA Negeri 4 Merangin. Secara khusus partisipan penelitian meliputi:

Tabel 1 Jumlah Responden

\begin{tabular}{lcc}
\hline \multicolumn{1}{c}{ Partisipan } & Jabatan & Keterangan \\
\hline Partisipan 1 & Kepala Sekolah & SMA Negeri 4 Merangin \\
Partisipan 2 & Pendidik & Guru SMA Negeri 4 Merangin \\
Partisipan 3 & Pendidik & Guru SMA Negeri 4 Merangin \\
Partisipan 4 & Pendidik & Guru SMA Negeri 4 Merangin \\
Partisipan 5 & Pendidik & Guru SMA Negeri 4 Merangin \\
Partisipan 6 & Tenaga & Kepala Tata Usaha Guru SMA Negeri 4 \\
& Administrasi & Merangin \\
Partisipan 7 & Peserta didik & Siswa SMA Negeri 4 Merangin \\
Partisipan 8 & Peserta didik & Siswa SMA Negeri 4 Merangin \\
Jumlah & 8 & \\
\hline
\end{tabular}

Teknik analisis data adalah penguraian sutau pokok atas berbagai bagiannya dan penelaahan bagian itu sendiri serta hubungan antar-bagian untuk memperoleh pengertian yang tepat dan pemahaman arti keseluruhan 
Basri, Khairinal dan Firman, Manajemen Kepala Sekolah dalam Meningkatkan Fungsi Guru di Sekolah Menengah Atas Negeri 4 Merangin

(Khairinal, 2018: 415-416). Teknik analisis data yang digunakan dalam penelitian ini adalah teknik Triangulasi dari tersebut (Miles dan Huberman, 2007: 434-437), Triangulasi dilakukan dalam usaha menghilangkan bias pemahaman peneliti dengan pemahaman subjek penelitian, dan merupakan teknik yang digunakan untuk menguji keterpercayaan data (memeriksa keabsahan data) dengan memanfaatkan hal-hal lain yang ada di luar data tersebut untuk keperluan mengadakan pengecekan atau sebagai pembanding terhadap data.

\section{HASIL DAN PEMBAHASAN}

Pada tahap perencanaan, kepala SMA Negeri 4 Merangin sudah berusaha merencanakan untuk meningkatkan fungsi guru secara sistematis menyeluruh. Dari sejumlah orang guru yang ada didorong untuk menekuni kewajibannya dengan penuh loyal dan konsisten mendidik dan mengajar serta mengabdi dengan penuh keikhlasan untuk sekolah sesuai visi dan misi. Hal ini sesuai dengan teori Arifin bahwa guru tidak hanya menjadi pengajar ilmu pengetahuan agama dan umum di kelas, tetapi ia juga sebagai norma-drager (pembawa norma) agamanya di tengah masyarakat. Itulah sebabnya, guru sekolah sebagai pemegang jabatan profesinal juga membawa misi keagamaan, yaitu misi agama dan misi ilmu pengetahuan (Permadi dan Arifin, 2007: 159-160).

Guru di SMA Negeri 4 Merangin tidak menganggap pekerjaan guru sebagai sambilan atau sementara, apabila ada pekerjaan yang lebih tinggi gajinya, maka statusnya sebagai guru akan ditinggalkan, sedangkan anak didiknya dibiarkan terlantar. Hal ini sesuai dengan teori Mulyasa, (2012: 5) guru merupakan komponen yang paling berperanguh terhadap terciptanya proses dan hasil pendidikan yang berkualitas. Perbaikan kualitas pendidikan harus berpangkal daari guru dan berujung pada guru pula.

Prinsip-prinsip peningkatan fungsi guru di SMA Negeri 4 Merangin berlandaskan pada nilai agama, keteladanan, berkesinambungan, Pada perencanaan, pihak SMA Negeri 4 Merangin sudah mengantisipasi kekurangan selama ini dengan melakukan perencanaan untuk meningkatkan fungsi guru sudah ada perintah lisan sangat dominan agar guru kuliah, guru PNS agar mengajukan sertifikasi, mengikuti penataran/ pelatihan/membuat perangkat mengajar dan diskusi sejawat. Sekolah memiliki kuasa mutlak, dan kebijakannya banyak bersifat lisan. Hal ini merupakan bagian dari keunikan sekolah yang bisa diterima secara fakta, meskipun rencana kerja secara teori harus tertulis. Perencanaan yang dilakukan kepala sekolah secara umum meliputi aspek keseluruhan pengelolaan sekolah kejuran.

Perencanaan ini dibuat SMA Negeri 4 Merangin untuk satu tahun pelajaran, dengan maksud agar pengelolaan sekolah kejuran bisa terlaksana secara maksimal dan terarah yang sesuai dengan pengembangannya. kepala sekolah memberikan tagihan-tagihan tertentu bagi setiap elemen sekolah agar bisa bekerja secara profesional sesuai dengan kompetensi yang dimilikinya. Rumusan perencanaan yang dilakukan kepala sekolah memang merupakan kerangka umum yang belum dijabarkan dalam unit-unit khusus, sehingga melalui fungsi-fungsi manajemen berikutnya perencanaan ini dijabarkan lebih lanjut. Rencana kerja juga sudah mengacu dan berdasarkan visi, misi dan tujuan sekolah. Hanya saja rencana yang ada kurang berdasarkan kebutuhan (need assessment), dan analisa jabatan pekerjaan (job analysis).

Pada tahap pengorganisasian, maka SMA Negeri 4 Merangin memandang semua guru sudah cakap untuk mengajar dan layak mendidik siswa-siswa pada bidang tugasnya masing-masing. Hal ini bisa dipahami bahwa SMA Negeri 4 Merangin sebagai lembaga sekolah, dengan ini memiliki otonomi mengatur dirinya sendiri, tanpa harus mengikuti standar pemerintah. sekolah dengan standar guru yang demikian tentu tidak masalah, sebab jika harus pelatihan, ada beberapa mata pelajaran di sekolah memang tidak ada program studinya di perguruan tinggi, misalnya nahwu, sharaf, mantik dan lainnya.

Pengalaman bekerja di sini adalah lamanya masa pengabdian yang telah dilalui oleh seorang guru dalam menjalani profesinya di SMA Negeri 4 Merangin. Pengalaman membelajarkan atau masa kerja guru merupakan salah satu faktor penentu keberhasilan dalam membelajarkan. Sebab semakin lama seseorang bergelut dalam suatu bidang kerja, itu akan mempengaruhi profesionalitas yang akan dimilikinya, hal ini sebagai suatu pertanda kematangan dalam jam kerja dan lamanya waktu pengabdian kerja akan berimplikasi terhadap kemampuan membelajarkan seorang guru.

Peningkatan fungsi guru mutlak dilakukan oleh kepala sekolah sebagai agen perubahan melalui kegiatan pembenahan kepemimpinan sekolah negeri dengan wadah pembinaan sosial yang tepat. Kinerja karyawan meningkat secara signifikan ketika mereka diberikan tujuan spesifik untuk melakukan daripada ketika mereka meninggalkan tanpa tujuan yang tidak jelas. Tujuan jelas atau 'melakukan yang terbaik' menghambat kreativitas dan usaha sehingga menjadi tidak termotivasi sedangkan penetapan tujuan yang menantang dan spesifik sangat penting untuk meningkatkan kinerja (Eshun \& Duah, 2011: 35).

Pengembangan guru kurang memperhatikan beberapa ketentuan pelaksanaan sistem SMA Negeri 4 Merangin. Ini dimaksudkan untuk menyesuaikan kebutuhan guru yang dikembangan dengan kondisi yang berkembang saat ini. Tidak dapat dibantah bahwa untuk menciptakan guru yang berkualitas, tentu memiliki tatanan kerja yang begitu 
Basri, Khairinal dan Firman, Manajemen Kepala Sekolah dalam Meningkatkan Fungsi Guru di Sekolah Menengah Atas Negeri 4 Merangin

komplek dan menyeluruh, meskipun pada pelaksanaannya mengalami kerumitan yang berarti, namun konsistensi dari penyelenggara pendidikan bisa menjadi kemajuan SMA Negeri 4 Merangin sebagai upaya pengembangan guru. Inilah penyesuaian kerja yang ada pada sistem SMA Negeri 4 Merangin terhadap kebutuhan guru.

Pada tahap penggerakan atau pelaksanaan, maka usaha peningkatan fungsi guru di SMA Negeri 4 Merangin sudah didukung oleh kemampuan manajerial sekolah negeri. SMA Negeri 4 Merangin berkembang dari tahun ke tahun. Fungsi guru di SMA Negeri 4 Merangin sangat khas, karena terkait dengan keikhlasan. Hasil eksplorasi peneliti, maka menemukan bahwa guru-guru di SMA Negeri 4 Merangin tidak mendapatkan gaji, sebab mereka 'diminta' untuk ikhlas dalam beramal di segala bidang sekolah. Kondisi ini sangat unik sebab bertentangan dengan teori umum bahwa fungsi guru berimplikasi pada hak mendapat penghargaan dalam bentuk materi maupun nonmateri.

Motivasi yang ada pada diri guru selama ini karena motif fisiologis, kebutuban sosial dan kebutuhan aktualisasi diri. Guru di sekolah sudah berusaha menenuhi tugasnya dengan profesional dengan memperhatikan hak-hak kerja. Manajemen SMA Negeri 4 Merangin dalam meningkatkan fungsi guru adalah mendorong guru bekerja secara kompeten. Kompetensi sangat dibutuhkan oleh guru. Kedudukan yang penting ini menyebabkan guru perlu mendapatkan pengembangan kemampuan dan profesionalitasnya. Kepemimpinan yang baik dapat meningkatkan kemampuan bawahan untuk menunjukkan kualitas kerja secara maksimal, sehingga pencapaian tujuan dapat dilakukan secara efisien dan efektif. Pemimpin, dalam kepemimpinannya menampilkan beragam model dan gaya yang akhirnya akan mengklasifikasikan pemimpin tersebut ke dalam tipe-tipe kepemimpinan tertentu. Di lapangan kepemimpinan di SMA Negeri 4 Merangin yang upaya meningkatkan fungsi guru sangat demokratis, sebab segala tugas berkaitan dengan peningkatan kompetensi, disiplin, penggajian dan pengembangan diri dirapatkan bersama-sama dengan guru.

Persoalan pelaksanaan manajemen peningkatan fungsi guru pada aspek kesejahteraan guru sudah dilakukan kepala sekolah dengan kesanggupan anggaran yang ada, meskipun belum sesuai dengan Upah Minimum Provinsi (UMP) Jambi dengan nilai Rp 1.900 .000 untuk tahun 2017. Masih banyak guru yang digaji di bawah angka ini. Mengaju pada teori dan peraturan tentang guru, maka melalui Undang-Undang Republik Indonesia Nomor 14 Tahun 2005 tentang Guru dan Dosen pasal 14 dikatakan bahwa dalam melaksanakan tugas keprofesional, guru berhak:

a. Memperoleh penghasilan di atas kebutuhan hidup minimum dan jaminan kesejahteraan sosial.

b. Mendapatkan promosi dan penghargaan sesuai dengan tugas dan prestasi kerja.

c. Memperoleh perlindungan dalam melaksanakan tugas dan hak atas kekayaan intelektual.

d. Memperoleh kesempatan untuk meningkatkan kompetensi.

e. Memperoleh dan memanfaatkan sarana dan prasarana pembelajaran untuk menunjang kelancaran tugas keprofesionalan.

f. Memiliki kebebasan dalam memberikan penilaian dan ikut menentukan kelulusan, penghargaan, dan/atau sanksi kepada peserta didik sesuai dengan kaidah pendidikan, kode etik guru, dan peraturan perundang-undangan.

g. Memperoleh rasa aman dan jaminan keselamatan dalam melaksanakan tugas.

h. Memiliki kebebasan untuk berserikat dalam organisasi profesi.

i. Memiliki kesempatan untuk berperan dalam penentuan kebijakan pendidikan.

j. Memperoleh kesempatan untuk mengembangkan dan meningkatkan kualifikasi akademik dan kompetensi.

k. Memperoleh pelatihan dan pengembangan profesi dalam bidangnya.

Para guru di SMA Negeri 4 Merangin selama ini hanya mendapatkan gaji pokok. Sedangkan tunjangan yang melekat pada gaji, serta penghasilan lain berupa tunjangan profesi, tunjangan fungsional, tunjangan khusus, dan maslahat tambahan. Para guru tidak mendapatkan jaminan kesejahteraan sosial dalam bentuk perlindungan kesehatan dan jiwa selama bekerja di SMA Negeri 4 Merangin.

\section{SIMPULAN}

Berdasarkan kepada permasalahan dan pertanyaan penelitian dan pembahasan yang telah dilakukan, maka dapat disimpulkan bahwa; 1) Kepala sekolah menyusun perencanaan dalam meningkatkan fungsi guru di SMA Negeri 4 Merangin yaitu memberikan kesempatan guru melakukan pengembangan diri seperti melanjutkan pendidikan ke Magister (S2), mengikuti pelatihan kurikulum 2013, menargetkan sertifikasi guru dan adaptasi guru terhadap Pendidikan Jarak Jauh (PJJ); 2) Kepala sekolah melakukan pengorganisasian dalam meningkatkan fungsi guru di SMA Negeri 4 Merangin yaitu pembagian tugas ditawarkan kepada setiap personil sesuai dengan kemampuannya yaitu pendidikan terakhir guru. Pengorganisasian juga ditentukan dari pengabdian guru kepada kepala sekolah dan adanya hubungan keluarga antara guru dan kepala sekolah. Pada aspek penggerakan kepala sekolah dalam meningkatkan fungsi guru di sekolah yaitu kepemimpinan dalam bentuk dorongan, komunikasi dan koordinasi kepada setiap personil untuk bekerja, meskipun kurang sesuai visi dan fasilitas yang terbatas jika melakukan pembelajaran Pendidikan . Guru tetap profesional bekerja dengan upah yang rendah karena adanya rasa pengabdian kepada kepala 
Basri, Khairinal dan Firman, Manajemen Kepala Sekolah dalam Meningkatkan Fungsi Guru di Sekolah Menengah Atas Negeri 4 Merangin

sekolah, memperbanyak pengalaman mengajar; 3) Kepala sekolah melakukan pengawasan dalam meningkatkan fungsi guru di SMA Negeri 4 Merangin yaitu pengawasan banyak diserahkan kepada wakil dan tidak dievaluasi secara berkala. kepala sekolah mendelegasikan persoalan teknis pengawasan kepada pihak sekolah dan jika ada persoalan urgensi diputuskan, maka pihak sekolah meminta pertimbangan dan keputusan kepala sekolah secara mutlak; 4) Kendala kepala sekolah dalam meningkatkan fungsi guru di SMA Negeri 4 Merangin adalah status guru belum semua PNS sehingga mempengaruhi kesejahteraan dan profesionalitas. Kemudian kualitas dan kuantitas media/alat praktikum masih terbatas serta anggaran yang belum mendukung operasional sekolah. Di samping peluang mengikuti pelatihan yang sedikit.

Berdasarkan hasil penelitian dan kesimpulan yang telah penulis uraikan, maka untuk meningkatkan Kualitas Manajemen Kepala Sekolah di masa yang akan datang penulis menyarankan: 1) kepada pihak sekolah agar memberikan izin belajar bagi guru yang akan meningkatkan kualifikasi pendidikan ke jenjang Magister (S2) dan izin bagi guru yang mengikuti pelatihan guru, 2) Pembinaan tenaga guru yang profesional perlu dilakukan, karena guru yang profesionalah yang akan mendukung peningkatan mutu pendidikan, dan 3) kepada pihak Sekolah bahwa ada satu pendekatan teori manajemen modern yang digunakan kajian ini sepenuhnya tidak mengena pada objek kajian sekolah negeri.

\section{DAFTAR PUSTAKA}

Creswell, J.W. 2011. Educational research. Boston: Pearson Education Inc.

Danim, S. 2013. Visi Baru Manajemen Sekolah. Jakarta: Bumi Aksara.

Engkoswara dan Aan Komariah. 2012. Administrasi pendidikan. Jakarta: Alfabeta.

Karwati, E. dan Donni Juni Priansa. 2013. Kinerja Profesionalisme Kepala Sekolah Membangun Sekolah yang Bermutu. Bandung: Alfabeta.

Khairinal. 2018. Penelitian Kualitatif: Teori, Model dan Skema. Jambi: Salim Media Indonesia.

Kompri. 2015. Manajemen pendidikan, Bandung: Alfabeta.

Miles, M.B. dan A.M. Huberman. 2007. Analisis Data Kualitatif: Buku Sumber Tentang Metode-Metode Baru Terj. Tjetjep Rohedi Rohidi Jakarta: UI Press.

Muhaimin. 2003. Wacana Pengembangan Pendidikan Islam, Surabaya: PSAPM.

Mukhtar \& Iskandar. 2013. Orientasi Baru Supervisi Pendidikan. Jakarta: Referensi.

Mulyasa, E. 2008 Standar Kompetensi dan Sertifikasi Guru. Cet. III. Bandung: Remaja Rosdakarya.

Nata, Abuddin. 2012. Kapita Selekta Pendidikan Islam. Jakarta: RajaGrafindo Persada.

Nurdin, Muhammad. 2004. Kiat Menjadi Guru Profesional. Jogyakarta: Prismasophie.

Permadi, D. dan Arifin, D. 2013. Panduan Menjadi Guru Profesional. Bandung: Nuansa Aulia.

Pramono, O. 2013. Leadership 1/2 Malaikat Solusi jitu Atasi Krisis Kepimimpinan Yogyakarta: Sura Media Utama.

Rosyada, D. 2003. Paradigma Pendidikan Demokratis, Jakarta: Kencana.

Sagala, S. 2009. Administrasi Pendidikan Kontemporer. Bandung: CV. Alfabeta.

Siagian, S.P. 1989. Fungsi-fungsi manajerial, Jakarta: Bina Aksara.

Stronge, J.H., Richard, HB. dan Catano, N. 2008. Qualities of Effective Principals, Terj. Siti Mahyuni. Alexandria VA, Association for Supervision dan Curriculum Development (ASCD) N. Beauregard St.

Sugiyono. 2014. Peta Jalan Pendidikan Indonesia. Yogyakarta: TIM Universitas Negeri Yogyakarta.

Wahab, AA. 2008. Anatomi organisasi dan kepemimpinan pendidikan. Bandung: Alfabeta.

Wahjosumidjo. 2007. Kepemimpinan kepala sekolah. Jakarta: RajaGrafindo Persada.

Yahya, M. 2013. Profesi tenaga kependidikan. Bandung: Pustaka Setia.

Zainuddin. 2007. Pendidikan Agama Islam. Jakarta: Bumi Aksara. 
Basri, Khairinal dan Firman, Manajemen Kepala Sekolah dalam Meningkatkan Fungsi Guru di Sekolah Menengah Atas Negeri 4 Merangin 